\title{
Kecemasan Mahasiswa Fakultas Dakwah Menghadapi Dunia Kerja ${ }^{1}$
}

\author{
Haryati \& Neneng Hasanah \\ Fakultas Dakwah UIN Sulthan Thaha Saifuddin Jambi \\ E-mail: nenenghasanah@uinjambi.ac.id
}

\begin{abstract}
This paper is motivated by research related to the anxiety felt by students of the Da'wah Faculty in facing the world of work. facing the working world, students need social support from the surrounding environment to reduce this anxiety. The relationship between social support and student anxiety in facing the world of work through a quantitative approach with multiple correlation methods. Non-Probability Sampling technique, Accidental Sampling technique is used in sampling. The research subjects were 101 students of the dakwah faculty, batch 2016. Based on the results of the research analysis, the correlation was 0.472 with a significance value of 0.000 ( $p$ $<0.05)$. The results of the pearson correlation $>r$ table are $0.472>0.195$, thus the research shows that the research hypothesis is accepted. (Ho is accepted, and Ha is rejected). so that there is a relationship between social support and student anxiety in facing the world of work in students of the Da'wah Faculty of the State Islamic University of Sulthan Thaha Saifuddin Jambi. With a pearson correltion value of 0.472, this indicates a strong correlation (correlation) between social support and student anxiety in facing the world of work.
\end{abstract}

Keywords: Working world, social support, anxiety.

Abstrak: Tulisan ini dilatarbelakangi oleh penelitian berkaitan kecemasan yang dirasakan oleh mahasiswa Fakultas Dakwah UIN Sulthan Thaha Saifuddin Jambi dalam menghadapi dunia kerja. menghadapi dunia kerja mahasiswa membutuhkan dukungan sosial dari lingkungan sekitar untuk mengurangi kecemasan tersebut. Hubungan antara dukungan sosial dengan kecemasan mahasiswa dalam menghadapi dunia kerja melalui pendekatan kuantitatif dengan metode korelasi multiple. Teknik Non-Probability menggunakan teknik Accidental Sampling digunakan dalam penarikan sampel. Subjek penelitian 101 mahasiswa fakultas dakwah angkatan 2016. Berdasar hasil analisis penelitian hasil korelasi sebesar 0,472 dengan nilai signifikansi sebesar $0,000(p<0,05)$. Hasil pearson correlation $>$ rtabel sebesar 0,472 >0,195, dengan demikian penelitian menunjukkan bahwa hipotesis penelitian diterima. (Ho diterima, dan Ha ditolak). sehingga terdapat hubungan antara dukungan sosial dengan kecemasan mahasiswa dalam menghadapi dunia kerja pada mahasiswa Fakultas Dakwah Universitas Islam Negeri Sulthan Thaha Saifuddin Jambi. Dengan nilai pearson correltion sebesar 0,472 hal ini menunjukkan adanya hubungan (korelasi) antara dukungan sosial dengan kecemasan mahasiswa dalam menghadapi dunia kerja yang cukup kuat.

Kata-kata kunci: Dunia kerja, dukungan sosial, kecemasan.

1 Tulisan ini adalah bagian dari penelitian penulis untuk karya ilmiah demi mendapat gelar strata satu Fakultas Dakwah UIN Sulthan Thaha Saifuddin Jambi yang dibimbing oleh M. Junaidi Habe, M.Si dan Neneng Hasanah, M.Pd.I. 


\section{Pendahuluan}

Mahbud Nadziri menjelaskan bahwa angka pengangguran yang tinggi di Indonesia disebabkan oleh munculnya ribuan lulusan dari universitas setiap tahunnya. Mayoritas dari lulusan tersebut merupakan pengangguran baru yang terus menambah angka pengangguran, hal ini ditunjukan dengan meningkatkatnya angka pengangguran yakni sebesar $20 \%$ dengan jumlah 695 ribu per tahun 2016. ${ }^{2}$ Peningkatakan angka pengangguran tersebut terjadi karena tingginya angka persaingan dalam dunia kerja, karena persaingan terjadi antar para pencari kerja dan mendapatkan pekerjaan pada era globalisasi bukanlah hal yang mudah.

Secara fundamental mendapatkan pekerjaan setelah lulus dari perguruan tinggi adalah impian pertama lulusan. Akan tetapi untuk mendapatkan pekerjaan tersebut para lulusan harus siap bersaing dengan lulusan dari perguruan tinggi lainnya. Persaingan yang terjadi setelah lulus membuat banyak lulusan yang mencari pekerjaan merasa cemas, khawatir dan tidak percaya diri. Menurut Kaplan dalam Widhi Nugrahaningtyas, dkk mengatakan bahwa kecemasan timbul karena individu merasa terancam oleh sesuatu hal yang dianggap menakutkan dan menyakitkan baik yang berasal dari dalam maupun dari luar dirinya. ${ }^{3}$ Kecemasan yang dialami seseorang dapat terjadi pada berbagai kondisi antara lain kecemasan pada masa depan. Kecemasan akan masa depan biasanya timbul dikarenakan faktor utama adalah dunia kerja. Muarifah menjelaskan bahwa kecemasan yang tidak teratasi dapat menyebabkan beberapa perilaku yang muncul, seperti perilaku yang menghindar. Perilaku tersebut biasanya akan menjadi hambatan individu untuk mendapatkan pekerjaan yang diinginkan. ${ }^{4}$

Kecemasan dalam menghadapi dunia kerja juga dirasakan oleh Mahasiswa Fakultas Dakwah UIN Sulthan Thaha Saifuddin Jambi. Secara akademik mahasiswa Fakultas Dakwah dituntut untuk menjadi kaum intelektual dengan bekal ilmu pengetahuan sesuai dengan jurusan masingmasing mahasiswa, hal tersebut bertujuan agar lulusan dari Fakultas Dakwah UIN Sulthan Thaha Saifuddin Jambi mampu menghadapi tantangan di dunia kerja. Faktanya dalam mengahadapi dunia kerja tidak hanya skill yang dibutuhkan, akan tetapi juga kesiapan fisik dan mental. Karena tingginya angka persaingan dalam dunia kerja maka para calon pencari kerja yang notabennya merupakan para mahasiswa mengalami kecemasan dalam menghadapi dunia kerja tersebut. Berdasarkan hasil observasi awal yang peneliti lakukan pada mahasiswa akhir semester 8 di tahun akademik

\footnotetext{
2 Mahbud Nadziri, Kecemasan Menghadapi Dunia Kerja pada Mahasiswa Akhir dengan Kejurusan yang Diprediksi Sulit Mendapat Pekerjaan, Malang: UMM, 2018, hlm. 2.

3 Widhi Nugrahaningtyas, Hubungan antara Efikasi Diri dan Dukungan Sosial Keluarga dengan Kecemasan Menghadapi Dunia Kerja pada Siwa Kelas XII SMK Muhammadiyah 1 Wedi Klaten, Jurnal Ilmiah Psikologi Candrajiwa, Vol. 3, No.2, 2014, hlm. 135.

${ }^{4}$ Mahbub Nadziri, Kecemasan menghadapi Dunia kerja pada Mahasiswa Akhir dengan Jurusan yang Diprediksi Sulit Mendapatkan Pekerjaan, Malang: UMM, 2018, hlm. 3.
} 
2019/2020 yang terdiri dari dua prodi yaitu prodi Bimbingan Penyuluhan Islam dan prodi Komunikasi Penyiaran Islam dengan jumlah sebanyak 136, serta hasil wawancara tidak terstruktur yang dilakukan oleh peneliti kepada mahasiswa akhir Fakultas Dakwah pada September 2019 menunjukan bahwa mereka mengalami rasa ketakutan tersendiri serta rasa cemas akan persaingan dunia kerja yang semakin ketat.

Pada dasarnya kecemasan dapat dihindari oleh setiap orang jika ia telah mengetahui faktor-faktor apa saja yang menimbulkan rasa cemas, selain itu juga bisa diatasi dengan berbagai macam cara. Namun, setiap orang memiliki cara masing-masing dalam mengatasi perasaan cemas yang mungkin saja tiba-tiba muncul. Dalam Islam cara mengatasi kecemasan yaitu dengan cara berdoa dan mengingat Allah melalui ibadah solat, bershalawat, berdzikir agar mendapatkan ketenangan. Selain itu dalam menghadapi kecemasan adalah dengan mencari dukungan sosial dari orang-orang terdekat, seperti orang tua, saudara, atau keluarga lainnya. Dukungan sosial sama seperti halnya energi positif yang akan mengurangi rasa cemas, gelisah, ataupun takut. Dukungan Sosial merupakan kenyamanan secara fisik dan psikologis yang diberikan orang lain yang bermanfaat ketika individu mengalami stres. ${ }^{5}$

Berdasarkan paparan di atas maka tujuan dalam penelitian ini adalah ingin mengetahui bagaimana hubungan dukungan sosial dengan kecemasan mahasiswa Fakultas Dakwah UIN Sultha Thaha Saifuddin dalam mengahadapi dunia kerja. Penelitian ini menggunakan pendekatan kuantitatif dengan teknik korelasi multifle. Populasi dalam penelitian ini adalah mahasiswa Fakultas Dakwah UIN Sultan Thaha Saifuddin Jambi semester 7 Angkatan 2019 yang berjumlah 136 orang. Mahasiswa Bimbingan Penyuluhan Islam berjumlah 62 orang dan Komunikasi Penyiaran Islam berjumlah 74 orang. Penelitian ini merupakan penelitian penulis dalam rangka menyelesaikan tugas akhir dan di bimbing oleh dua orang dosen, yang juga menjadi author dalam tulisan ini.

\section{Kecemasan Mahasiswa}

Kecemasan adalah salah satu emosi yang dimiliki oleh manusia yang timbul karena adanya tekanan baik dari dalam diri maupun dari luar manusia. Kecemasan bisa juga disebut sebagai suatu bentuk kekhawatiran mengenai suatu peristiwa yang akan datang dan peristiwa yang belum diketahui mengenai kejelasan ataupun kebenarannya. Sehingga jika seseorang sedang mengalami kecemasan akan merasa kurang percaya diri dan merasa rendah diri.

Kartono dalam Ernia Yunita berpendapat bahwa kecemasan merupakan reaksi emosi yang tidak menyenangkan yang ditandai dengan

${ }^{5}$ Widhi Nugrahaningtyas, Hubungan antara Efikasi Diri dan Dukungan Sosial Keluarga dengan Kecemasan Menghadapi Dunia Kerja pada Siswa Kelas XII SMK Muhammadiyah 1 Wedi Klaten, Jurnal Ilmiah Psikologi Candrajiwa, Vol. 3, No. 2, 2014, hlm. 137. 
ketakutan. Perasaan takut itu timbul karena adanya ancaman atau gangguan terhadap suatu objek yang masih abstrak, serta rasa takut yang bersifat subjektif, hal ini ditandai dengan adanya perasaan tegang, khawatir dan sebagainya. ${ }^{6}$ Salah satu bentuk kecemasan yang dapat terjadi pada mahasiswa yaitu kecemasan menghadapi dunia kerja.

Kecemasan merupakan pengalaman subjektif yang tidak menyenangkan mengenai kekhawatiran atau ketegangan berupa perasaan cemas, tegang dan emosi yang dialami oleh seseorang. Kecemasan adalah suatu keadaan tertentu (state anxiety), yaitu menghadapi situasi yang tidak pasti dan tidak menentu terhadap kemampuannya dalam menghadapi suatu objek. Hal tersebut berupa emosi yang kurang menyenangkan yang dialami oleh individu akan tetapi kecemasan tersebut bukanlah sebagai sifat yang melekat pada kepribadian. ${ }^{7}$

Tokoh akademik penting yang membahas teori tentang kecemasan adalah Sigmun Freud. Kecemasan menurut Freud adalah suatu keadaan perasaan afektif yang tidak menyenangkan yang disertai dengan sensasi fisik yang memperingatkan orang terhadap bahaya yang akan datang. Keadaan yang tidak menyenangkan itu sering kabur dan sulit menunjuk dengan tepat, tetapi kekecewaan itu sendiri selalu dirasakan. Freud juga menjelaskan adanya pembagian kecemasan yaitu: a) Kecemasan neurotik adalah ketakutan terhadap suatu bahaya yang tidak diketahui. Kecemasan ini berkaitan dengan ketakutan dalam menerima hukuman yang bersumber dari orang tua, guru atau majikan. Sehingga ketakutan tersebut berkembang menjadi kecemasan neurotik yang tidak disadari. Kecemasan neurotik ini yaitu rasa takut yang dimiliki oleh individu, sepert "insting-insting akan lepas dari kendali dan menyebabkan sang pribadi berbuat sesuatu yang bisa membuatnya dihukum; b) Kecemasan moral terjadi bila kita gagal melakukan apa yang dianggap baik atau benar secara moral. Misalnya, tidak bisa memelihara atau memperhatikan orang tua kita atau membantu anak-anak kita dengan baik; c) Kecemasan realistik adalah kecemasan yang juga dikenal sebagai kecemasan objektif, yang hampir sama dengan ketakutan. Kecemasan realistik ini dapat didefinisikan sebagai perasaan yang tidak menyenangkan dan tidak spesifik terhadap suatu bahaya yang mungkin terjadi. Misalnya kecemasan saat mengendarai mobil kemudian ditengah jalan mobilnya mengalami kecelakaan.

Jika dilihat dari ketiga jenis kecemasan yang telah dijelaskan oleh Freud, kecemasan dalam menghadapi dunia kerja masuk kedalam kecemasan realistik di mana mahasiswa yang telah lulus perguruan tinggi memiliki ketakutan tersendiri saat menghadapi dunia kerja. Ketakutan-ketakutan yang dialami mahasiswa ini terkait tentang takut tidak lulus seleksi dalam

6 Ernia Yunita, Hubungan antara Kepercayaan Diri dengan Kecemasan Menghadapi Dunia Kerja pada Mahasiswa Semester Akhir Universitas Muhammadiyah Surakarta, Surakarta: UMS, 2013, hlm. 1.

7 M. Nur Ghufron \& Rini Risnawati S, Teori-teori Psikologi, Jogyakarta: AR-RUZZ MEDIA,, 2017, hlm. 141. 
penerimaan pegawai negeri sipil, kemudia takut tidak memiliki kompetensi yang memadai untuk dapat diterima di kantor yang dikehendaki. Selain itu akhir-akhir ini ketakutan yang mendalam juga dialami mahasiswa yaitu takut kalah dalam bersaing dengan pencari pekerjaan lainnya yang datang dari perguruan-perguruan tinggi negeri yang ada di Indonesia. ${ }^{8}$

Kedua Teori Kecemasan Nietzal. Nietzal dalam M. Nur Ghufron \& Rini Risnawati berpendapat bahwa kecemasan berasal dari bahasa latin (anxius) dan dari bahasa Jerman (anst), yaitu suatu kata yang digunakan untuk menggambarkan efek negative dan rangsangan fisiologi. ${ }^{9}$

Ketiga Teori Kecemasan Lazarus. Lazarus membedakan perasaan cemas menurut penyebabnya menjadi dua bagian yaitu : a) State anxiety adalah reaksi emosi sementara yang timbul pada situasi tertentu yang dirasakan sebagai ancaman, misalnya mengikuti tes, menjalani operasi, atau lainnya. Keadaan ini ditentukan oleh perasaan tegang yang subjektif; b) Trait anxiety adalah disposisi untuk menjadi cemas dalam menghadapi berbagai macam situasi (gambaran kepribadian), ini merupakan ciri atau sifat yang cukup stabil yang mengarahkan seseorang atau menginterpretasikan suatu keadaan menetap pada individu (bersifat bawaan) dan berhubungan dengan kepribadian yang demikian. ${ }^{10}$

Dari beberapa pendapat di atas, dapat disimpulkan bahwa kecemasan merupakan suatu keadaan tertentu (state anxiety). Misalnya ketika menghadapi situasi yang belum pasti dan tidak menentu terhadap kemampuannya dalam menghadapi tes, berupa emosi yang kurang menyenangkan yang dialami oleh individu, akan tetapi kecemasan bukanlah sifat yang melekat pada kepribadiannya.

Menurut Nevid dkk, dalam Daniel Rizky Wijaksono kecemasan memiliki tiga aspek, yaitu; a) Simptom Fisik yaitu gangguan yang terjadi pada fisik individu yang mengalami kecemasan, seperti keluar banyak keringat, badan gemetar, jantung berdetak kencang, sulit bernafas, pusing, tangan dingin, mual, panas dingin, lebih sensitive, mengalami kegelisahan, mengalami kegugupan, pingsan, merasa lemas, sering buang air kecil dan diare; b) Simptom Kognitif adalah perasaan khawatir yang timbul tentang sesuatu dan memiliki keyakinan bahwa sesuatu yang mengerikan akan terjadi. Selain itu, individu akan merasa terancam oleh seseorang ataupun suatu peristiwa, serta merasa kebingungan dan khawatir jika ditinggal sendiri; c) Simptom Perilaku adalah kecemasan yang mengakibatkan perilaku individu menjadi berbeda dan mengarah kepada hal yang yang kurang biasa, seperti halnya

8 Calvin S Hall \& Cardner Lindzey, Psikologi Kepribadian 1 Teori-Teori Psikodinamik (Klinis), Yogyakarta: Kanisius, 2005, hlm. 81.

${ }_{9}^{9}$ M. Nur Ghufron \& Rini Risnawati S, Teori-teori Psikologi, Jogyakarta: Ar-Ruzz Media, 2017, hlm. 141 - 142.

${ }^{10}$ M. Nur Ghufron \& Rini Risnawati S, Teori-teori Psikologi, hlm. 142. 
perilaku menghindar, perilaku ketergantungan, perilaku terguncang, dan meninggalkan situasi yang menimbulkan kecemasan. ${ }^{11}$

Adler dan Rodman dalam M. Nur Ghufron mengatakan terdapat dua faktor yang menyebabkan adanya kecemasan, yaitu: a) Pengalaman negatif pada masa lalu merupakan hal yang tidak menyenangkan pada masa lalu mengenai peristiwa yang dapat terulang lagi pada masa mendatang. Apabila individu tersebut menghadapi situasi atau kejadian yang sama dan juga tidak menyenangkan, misalnya pernah gagal tes, hal tersebut merupakan pengalaman umum yang menimbulkan kecemasan siswa dalam menghadapi tes; b) Pikiran yang tidak rasional, para psikolog memperdebatkan bahwa kecemasan terjadi bukan karena suatu kejadian, melainkan kepercayaan atau keyakinan tentang kejadian itulah yang menjadi penyebab kecemasan.

Ellis memberi daftar kepercayaan atau keyakinan kecemasan, sebagai contoh dari pikiran tidak rasional yang disebut buah pikiran yang keliru, yaitu kegagalan katastropik, kesempurnaan, persetujuan, dan generalisasi yang tidak tepat. ${ }^{12}$ Secara umum faktor-faktor yang menyebabkan timbulnya kecemasan adalah faktor internal dan faktor eksternal. Faktor internal meliputi tingkat religiusitas yang rendah pada diri individu, kemudian tingginya rasa pesimis, takut gagal, pengalaman negatif masa lalunya, dan juga pikiran yang tidak rasional. Sementara faktor eksternal seperti kurangnya dukungan sosial pada diri individu tersebut.

Dunia kerja adalah dunia baru yang akan dimasuki oleh orang yang telah selesai menempuh pendidikanya. Dunia kerja memiliki beberapa bidang, dimana setiap karyawan dituntut memiliki kemampuan, keahlian serta keterampilan khusus yang dibutuhkan setiap dunia kerja. Oleh karena itu mahasiswa Fakultas Dakwah mengalami kecemasan dalam memasuki dunia kerja. Kecemasan menghadapi dunia kerja adalah penilaian dari individu terhadap pencapaian tujuan mengenai dunia kerja yang belum pasti. Sehingga mengakibatkatkan individu mengalami konflik dalam diri yang menyebabkan perubahan tingkah laku seperti menghindari segala sesuatu yang berkaitan dengan dunia kerja dan juga tergangguanya respon fisiologi lainnnya

\section{Dukungan Sosial}

Dukungan sosial merupakan salah satu fungsi dari ikatan sosial. Dimana ikatan-ikatan tersebut menggambarkan tingkat kualitas umum dari hubungan interpersonal. Dukungan sosial juga dapat dikatakan sebagai suatu proses sosial, emosional, pembelajaran (kognitif), dan perilaku yang terjadi dalam hubungan antar individu. Pemberian dukungan sosial ini dapat

11 Daniel Rizky Wijaksono, Hubungan Antara Dukungan Sosial Dengan Kecemasan Dalam Menghadapi Dunia Kerja Pada Siswa Smk, Yogyakarta: USD, 2016, hlm. 10 - 11.

12 M. Nur Ghufron \& Rini Risnawati S, Teori-teori Psikologi, Jogyakarta: Ar-Ruzz Media, 2017, hlm. 143 - 147. 
meringankan permasalahan yang dialami oleh individu. Saat seseorang mendapatkan dukungan keluarga semuanya akan terasa mudah. Individu yang mendapatkan dukungan sosial akan merasa dihargai, disayangi dan diperhatikan. Sehingga hal tersebut tentu baik untuk psikisnya serta mengurangi kecemasan yang ia alami. Dukungan keluarga yang dapat diberikan kepada individu dapat berupa dukungan moral (motivasi), kemudian dukungan finansial yaitu memberikan fasilitas-fasilitas penunjang individu dalam mengatasi kecemasan dalam menghadapi dunia kerja. Selain itu juga keluarga dapat memberikan dukungan informatif berupa pemberian informasi lowongan pekerjaan, kemudain memberikan saran, nasihat serta memberikan pendidikan yang baik untuk si anak agar anak memiliki prestasi akademik. Sehingga anak mampu bersaing dengan pencari kerja yang lainnya.

Sarason dalam Fani Kumala Sari menjelaskan bahwa dukungan sosial adalah keberadaan, kesediaan, kepedulian dari orang-orang yang dapat diandalkan, menghargai dan menyayangi kita. Sarason berpendapat bahwa dukungan sosial itu selalu mencakup atas dua hal yaitu: a) Jumlah sumber dukungan sosial yang tersedia, merupakan persepsi individu terhadap sejumlah orang yang dapat diandalkan saat individu membutuhkan bantuan (pendekatan berdasarkan kuantitas); b) Tingkatan kepuasan akan dukungan sosial yang diterima, berkaitan dengan persepsi individu bahwa kebutuhannya akan terpenuhi (pendekatan berdasarkan kualitas).

Hal di atas perlu dipahami oleh individu yang akan memberikan dukungan sosial karena menyangkut persepsi tentang keberadaan (availabilit) dan ketepatan (adequancy) dukungan sosial terhadap seseorang. ${ }^{13}$ Dukungan sosial bukan hanya perihal pemberian bantuan saja, melaikan yang penting adalah bagaimana persepsi si penerima memaknai bantuan yang diberikan.

Dukungan sosial dibedakan menjadi empat aspek yaitu : a) Dukungan emosional yaitu mencakup ungkapan empati, kepedulian, dan perhatian terhadap orang yang bersangkutan; b) Dukungan penghargaan merupakan dukungan yang terjadi lewat ungkapan hormat/penghargaan positif untuk orang lain itu, dorongan maju atau persetujuan dengan gagasan atau perasaan individu, dan perbandingan positif orang itu dengan orang lain; c) Dukungan instrumental yakni dukungan yang berbentuk bantuan langsung, misalnya orang memberi pinjaman uang kepada orang yang membutuhkan atau menolong dengan memberi pekerjaan pada orang yang tidak mempunyai pekerjaan; d) Dukungan Informatif yakni mencakup pemberian nasihat, saran, pengetahuan, dan informasi serta petunjuk.

Hampir setiap orang tidak mampu menyelesaikan masalahnya sendiri, tetapi mereka membutuhkan bantuan orang lain sebagai bentuk dari dukungan sosial (Sosial Support). Dukungan sosial merupakan mediator yang penting dalam menyelesaikan masalah seseorang, hal ini karena individu

13 Fani kumalasari, Hubungan Antara Dukungan Sosial Dengan Penyesuaian Diri Remaja Di Panti Asuhan, Jurnal Psikologi Pitutur, Vol. 1, No.1, 2012, hlm. 25. 
merupakan bagian dari keluarga, teman sekolah ataupun teman kerja, kegiatan agama ataupun bagian dari kelompok lainnya. Dimensi dukungan sosial meliputi 3 hal yaitu: a) Emotional support, meliputi: perasaan nyaman, dihargai, dicintai, dan diperhatikan; b) Cognitive support, meliputi: Informasi, pengetahuan, dan nasihat; c) Materials support, meliputi: bantuan atau pelayanan berupa sesuatu barang dalam mengatasi suatu masalah. ${ }^{14}$

\section{Temuan Penelitian}

\section{A. Hasil Uji Validitas dan Reliabilitas}

Instrumen yang digunakan dalam penelitian ini berupa angket kuisoner. Angket kuisioner digunakan untuk mengukur tingkat dukungan sosial dan kecemasan mahasiswa dalam menghadapi dunia kerja dengan menggunakan skala likert dengan empat alternatif jawaban yaitu sangat setuju, setuju, tidak setuju, dan sangat tidak setuju. Pengujian data untuk uji validitas dan reabilitas alat ukur dilakukan dengan menggunakan software SPSS 16.0 for windows. Indeks validitasi dan reabilitasi yang didapat dari proses analisis ini berguna untuk melakukan seleksi item angket. Angket dinyatakan valid apabila nilai signifikansi kurang dari 0,05 (sig <0,05). Angket dinyatakan reliabilitas apabila nilai Cronbach's Alpha lebih dari 0,6.

a Skala Dukungan Sosial

Hasil analisis uji coba menunjukkan bahwa dari 20 Item dinyatakan semua item valid. Dinyatakan valid karena dari hasil uji validitas nilai signifikansi dukungan sosial yaitu $<0,05$.

b. Skala Kecemasan Dalam Menghadapi Dunia Kerja

Hasil analisis uji coba menunjukkan bahwa dari 20 Item terdapat 19 item yang dinyatakan valid dan 1 item dinyatakan tidak valid. Adapun item yang tidak valid yaitu nomor 19. Sementara item yang dinyatakan valid yaitu nomor $1,2,3,4,5,6,7,8,9,10,11,12,13,14,15,16,17,18,20$.

1. Penyajian Data

Data yang disajikan dalam penelitian ini meliputi skor tertinggi (Maximum), skor terendah (Minimum), skor rata-rata (Mean), Standar Deviasi (SD), distribusi frekuensi, dan tampilan diagram batang. Data yang disajikan diolah menggunakan program SPSS versi 16.0. Deskripsi data penelitian dapat dijelaskan sebagai berikut:

Descriptive Statistic

\begin{tabular}{|l|c|c|c|c|c|}
\hline & $\mathrm{N}$ & Maximum & Minimum & Mean & $\begin{array}{c}\text { Std. } \\
\text { Devisiasion }\end{array}$ \\
\hline $\begin{array}{l}\text { Dukungan } \\
\text { Sosial }\end{array}$ & 101 & 80 & 49 & 66.45 & 4.642 \\
\hline
\end{tabular}

14 Nursallam, Ninuk Dian Kurniawati, Asuhan Keperawatan Pada Pasien Terinfeksi, Jakarta: Salemba Medika, 2007, hlm. 29 - 30. 


\begin{tabular}{|l|l|l|l|l|l|}
\hline Kecemasan & 101 & 80 & 34 & 55.82 & 8.074 \\
$\begin{array}{l}\text { Dalam } \\
\text { Menghadapi } \\
\text { Dunia Kerja }\end{array}$ & & & & & \\
\hline
\end{tabular}

Berdasarkan tabel diatas, didapat skor hasil untuk dukungan sosial dan kecemasan mahasiswa dalam menghadapi dunia kerja dari jumlah sampel ( N ) sebanyak 101 mahasiswa. Skor dukungan sosial diperoleh hasil tertinggi (maximum) adalah 80, skor terendah (minimum) adalah 49, dan skor ratarata (mean) yaitu sebesar 66.45. Sedangkan untuk skor kecemasan dalam menghadapi dunia kerja yaitu diperoleh hasil tertinggi (maximum) adalah 80, skor terendah (minimum) sebesar 34, untuk skor rata-rata (mean) sebesar 55.92.

Dukungan Sosial dengan jumlah 101 mahasiswa Fakultas Dakwah Universitas Islam Negeri Sulthan Thaha Saifuddin Jambi sebagai sampel. Berdasarkan skor perhitungan angket dukungan sosial yang diolah menggunakan program SPSS versi 16.0, maka diperoleh data dukungan sosial pada penelitian ini dapat dijelaskan sebagai berikut:

Skor Empirik Dukungan Sosial

\begin{tabular}{|c|c|c|c|c|c|}
\hline Variabel & $\mathrm{N}$ & Maximum & Minimum & Mean & $\begin{array}{c}\text { Std. } \\
\text { Devisiasion }\end{array}$ \\
\hline $\begin{array}{c}\text { Dukungan } \\
\text { Sosial }\end{array}$ & 101 & 80 & 49 & 66.45 & 4.642 \\
\hline
\end{tabular}

Dari tabel diatas, diketahui skor tertinggi (maximum) sebesar adalah 80 dan skor terendah (minimum) sebesar adalah 49, dengan skor rata-rata (mean) sebesar adalah 66.45 dan Std. Devisiasion (SD) sebesar adalah 4.642. Nilai dapat dinyatakan dalam bentuk histogram berikut ini:

\section{Diagram Batang Dukungan Sosial}

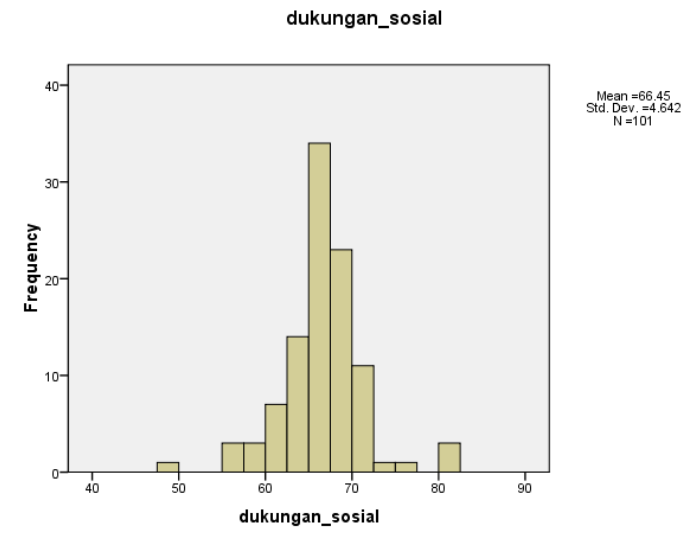


Penarikan kesimpulan dilakukan berdasarkan hasil analisis skor empirik dukungan sosial yaitu dengan melakukan perhitungan skor maksimal dikurangkan dengan skor minimal untuk didapatkan nilai interval, kemudian disusun kategori dukungan sosial berdasarkan 3 kategori yang dinyatakan sebagai berikut:

$$
\begin{aligned}
\mathrm{N} & =\Sigma \text { Max }-\Sigma \text { Min } \\
& =80-49 \\
& =31
\end{aligned}
$$

Kemudian, untuk menentukan nilai interval maka diperoleh hasil $31: 3=10.3$

Kategori Dukungan Sosial

\begin{tabular}{|c|c|c|c|c|}
\hline NO & Skor & Kategori & Jumlah & Persentase \\
\hline 1. & $49.0-59.3$ & Rendah & 8 & $8 \%$ \\
\hline 2. & $59.4-69.7$ & Sedang & 66 & $65.34 \%$ \\
\hline 3. & $69.8-80.1$ & Tinggi & 27 & $27 \%$ \\
\hline
\end{tabular}

Berdasarkan tabel diatas, dapat kita ketahui bahwa dari 101 mahasiswa semester 8 Fakultas Dakwah Universitas Islam Negeri Sultan Thaha Saifuddin Jambi, sebanyak 8 (8\%) memiliki tingkat dukungan sosial yang rendah dan sebanyak 66 (65.43\%) memiliki tingkat dukungan sosial sedang. Kemudian sebanyak 27 (27\%) memiliki tingkat dukungan sosial tinggi.

Kecemasan dalam menghadapi dunia kerja dengan jumlah 101 mahasiswa semester 8 Fakultas Dakwah Universitas Islam Negeri Sulthan Thaha Saifuddin Jambi sebagai sampel. Berdasarkan skor perhitungan angket dukungan sosial yang diolah menggunakan program SPSS versi 16.0, maka diperoleh data dukungan sosial pada penelitian ini dapat dijelaskan sebagai berikut.

Skor Empirik Kecemasan dalam Menghadapi Dunia Kerja

\begin{tabular}{|c|l|l|l|l|l|}
\hline Variabel & $\mathrm{N}$ & Maximum & Minimum & Mean & $\begin{array}{c}\text { Std. } \\
\text { Devisiasion }\end{array}$ \\
\hline Kecemasan & 101 & 80 & 34 & 55.82 & 8.074 \\
\hline
\end{tabular}

Dari tabel diatas, diketahui skor tertinggi (maximum) sebesar adalah 80 dan skor terendah (minimum) sebesar adalah 34, dengan skor rata-rata (mean) sebesar adalah 55.82 dan Std. Devisiasion (SD) sebesar adalah 8.074. Nilai dapat dinyatakan dalam bentuk histogram berikut ini: 
Diagram Batang Kecemasan menghadapi dunia kerja

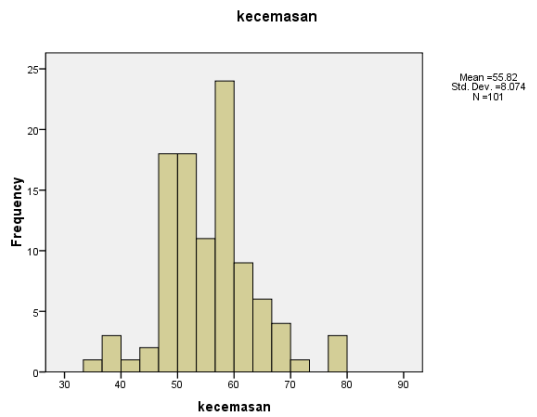

Penarikan kesimpulan dilakukan berdasarkan hasil analisis skor empirik kecemasan menghadapi dunia kerja yaitu dengan melakukan perhitungan skor maksimal dikurangkan dengan skor minimal untuk didapatkan nilai interval, kemudian disusun kategori dukungan sosial berdasarkan 3 kategori yang dinyatakan sebagai berikut:

$$
\begin{aligned}
\mathrm{N} & =\Sigma \mathrm{Max}-\Sigma \mathrm{Min} \\
& =80-34 \\
& =46
\end{aligned}
$$

Kemudian, untuk menentukan nilai interval maka diperoleh hasil $46: 3=15,3$.

Kategori Kecemasan Menghadapi Dunia Kerja

\begin{tabular}{|c|c|c|c|c|}
\hline NO & Skor & Kategori & Jumlah & Persentase \\
\hline 1. & $34.0-49.3$ & Rendah & 21 & $21 \%$ \\
\hline 2. & $49.4-64.7$ & Sedang & 68 & $67.32 \%$ \\
\hline 3. & $64.8-80.1$ & Tinggi & 12 & $12 \%$ \\
\hline
\end{tabular}

Berdasarkan tabel diatas, dapat kita ketahui bahwa dari 101 mahasiswa semester 8 Fakultas Dakwah Universitas Islam Negeri Sulthan Thaha Saifuddin Jambi, sebanyak 21 (21\%) memiliki tingkat kecemasan dalam menghadapi dunia kerja rendah. Dan sebanyak 68 (67.32 \%) memiliki tingkat kecemasan dalam menghadapi dunia kerja sedang. Kemudian sebanyak 12 (12\%) memiliki tingkat kecemasan dalam menghadapi dunia kerja tinggi.

2. Pengujian Persyaratan Analisis

Sebelum dilakukan analisis data terlebih dahulu dilakukan uji prasyaratan analisis yang terdiri dari uji normalitas dan uji linieritas. Pengujian analisis data ini dilakukan dengan menggunakan bantuan program spss versi 16.0. Berikut penjelasan pengujian persyaratan analisis sebagai berikut:

a. Uji Normalitas

Uji normalitas digunakan untuk mengetahui sebaran data angket dukungan sosial dengan kecemasan mahasiswa dalam menghadapi dunia kerja 
berdistribusi normal atau tidak. Standard yang digunakan untuk mengetahui normal atau tidaknya sebaran data yaitu jika nilai $\mathrm{p}>0,05$ maka sebaran data tersebut dinyatakan normal. Dan jika nilai $\mathrm{p}<0,05$ maka sebran data dinyatakan tidak normal. ${ }^{15}$

Dalam teknik pengujian normalitas ini menggunakan teknik Test of Normality Kolmogorov. Hasil uji normalitas kedua variabel tersebut dapat dilihat pada tabel sebgai berikut:

\begin{tabular}{|l|l|l|}
\hline \multicolumn{1}{|c|}{ Hasil Uji Normalitas } \\
\hline $\begin{array}{l}\text { Variabel } \\
\begin{array}{l}\text { Sosial*Kecemasan } \\
\text { Menghadapi dunia kerja }\end{array}\end{array}$ & $\begin{array}{c}\text { Kolmogorov- } \\
\text { Smirnov Z }\end{array}$ & $\begin{array}{c}\text { Asymp. Sig. (2- } \\
\text { tailed) }\end{array}$ \\
\hline
\end{tabular}

Berdasarkan table output SPSS versi 16.0 pada uji normalitas dengan rumus Kolmogrov-Smimov, yaitu dengan perhitungan jika nilai signifikansi (sig) > 0,05 maka hasil data dikatakan berdistribusi normal.Hasil analisis diketahui bahwa nilai Asymp. Sig. (2-tailed) untuk dukungan sosial dan kecemasan mahasiswa dalam menghadapi dunia kerja yaitu sebesar 0.735lebih besar dari 0.05. maka dapat disimpulkan bahwa data berdistribusi normal.

b. Uji Linieritas

Uji linieritas hubungan dalam penelitian ini menggunakan ujiF. Dengan menggunakan bantuan program SPSS versi 16.0 untuk menguji deviation from linearity dari F linear. kriteria pengambilan keputusan hubungan antara variabel independent dengan variabel dependent linear dapat dilakukan dengan dua cara yaitu: a) Berdasarkan nilai F yaitu apabila Fhitung > Ftabel maka dapat dikatakan bahwa terdapat hubungan linier yang signifikan; b) Berdasarkan nilai yang diperoleh dari Deviation From Linearity Sig (p) pada hasil output SPSS lebih besar dari 0.05 maka dikatakan bahwa terdapat hubungan linier yang signifikan. ${ }^{16}$

Uji Linieritas

\begin{tabular}{|c|c|c|c|}
\hline Variabel & Fhitung & Ftabel & Hasil \\
\hline $\begin{array}{c}\text { Dukungan Sosial } \\
\text { * Kecemasan dalam } \\
\text { menghadapi dunia } \\
\text { kerja }\end{array}$ & 8.36 & 3.97 & Linier \\
\hline
\end{tabular}

${ }^{15}$ Edy, SPSS + AMOS, Bogor: In Media, 2014, Hlm. 86.

${ }^{16}$ Edy, SPSS + AMOS, hlm. 92. 
Berdasarkan tabel uji linearitas, didapatkan hasil dari nilai Fhitung hubungan antara variabel X-Y dengan nilai Fhitung lebih besar dari pada Ftabel. Dengan nilai $(8,36>3.97)$, sehingga dapat disimpulkan bahwa terdapat hubungan linier yang signifkan antara dukungan sosial dengan kecemasan mahasiswa dalam menghadapi dunia kerja. Berdasarkan hasil output perhitungan SPSS diperoleh hasil $p=0,654$, dimana nilai $p>0,05$. Sehingga dapat disimpulkan bahwa terdapat hubungan linier yang signifikan antara dukungan sosial dengan kecemasan mahasiswa dalam menghdapi dunia kerja.

c. Uji Hipotesis

Pengujian hipotesis dilakukan dengan menggunakan teknik korelasi product moment dengan bantuan program SPSS versi 16.0 untuk mencari korelasi antara variabel $(\mathrm{X})$ dan variabel $(\mathrm{Y})$. dari perhitungan korelasi diperoleh hasi sebagai berikut:

Uji Hipotesis

\begin{tabular}{|c|c|c|c|}
\hline & $\mathrm{N}$ & Sig & $\begin{array}{c}\text { Pearson } \\
\text { Correlation }\end{array}$ \\
\hline $\begin{array}{c}\text { Dukungan Sosial } \\
\text { (Religiusitas) }\end{array}$ & 101 & .000 & 472 \\
\hline $\begin{array}{c}\text { Kecemasan } \\
\text { menghadapi dunia } \\
\text { kerja (Agresifitas) }\end{array}$ & 101 & .000 & 472 \\
\hline
\end{tabular}

Berdasarkan pada tabel di atas, diperoleh hasil dari perhitungan korelasi product moment nilai koefisien korelasi antara dukungan sosial dengan kecemasan dalam menghadapi dunia kerja sebesar 0,472, dengan taraf signifikansi 5\% dan $\mathrm{N}=101$ dengan signifikansi atau probalitas 0, 000 yang berarti lebih kecil dari 0, $05(\mathrm{p}<0,05)$. Harga koefisien rtabel dengan taraf signifikansi 5\% dan $\mathrm{N}=101$ yaitu sebesar 0,195. Dengan hasil pearson correlation sebesar 0.472 lebih besar dari pada rtabel 0,195 maka hasil ini menujukan bahwa pearson correlation > rtabel sehingga Ho ditolak dan $\mathrm{Ha}$ diterima. Ini berarti dapat disimpulkan bahwa terdapat hubungan yang signifikan antara dukungan sosial dengan kecemasan mahasiswa dalam menghadapi dunia kerja pada mahasiswa Fakultas Dakwah Universitas Islam Negeri Sulthan Thaha Saifuddin Jambi.

\section{Pembahasan Temuan Penelitian}

Penelitian ini memiliki tujuan untuk mengetahui hubungan antara dukungan sosial dengan kecemasan mahasiswa dalam menghadapi dunia kerja pada mahasiswa Fakultas Dakwah Universitas Islam Negeri Sulthan Thaha Saifuddin Jambi . Dari hasil uji hipotesis yang dilakukan, didapatkan koefisien korelasi sebesar 0,472 dengan nilai signifikansi sebesar 0, $000(\mathrm{p}<0,05)$. Dengan hasil pearson correlation $>$ rtabel sebesar $0,472>0,195$ sehingga 
hipotesis Ho ditolak dan Ha diterima. Jika dilihat dari nilai pearson correlation sebesar 0,472 itu berarti hubungan kedua variabel menunjukkan hubungan yang cukup kuat.

Berdasarkan hasil tersebut menunjukkan bahwa hipotesis penelitian Ha diterima. Jadi terdapat hubungan antara dukungan sosial dengan kecemasan mahasiswa dalam menghadapi dunia kerja pada mahasiswa Fakultas Dakwah Universitas Islam Negeri Sulthan Thaha Saifuddin Jambi. Dukungan sosial dapat memberikan efek yang besar terhadap perilaku seseorang yang sedang mencari pekerjan. Dengan adanya dukungan sosial yang diberikan baik dari keluarga, teman sebaya maupun lingkungan. Hal ini dapat mengurangi tingkat kecemasan dan ketakutan yang dialami mahasiswa dalam menghadapi dunia kerja.

Hal ini juga selaras dengan penelitian yang dilakukan oleh Devinda dan Yeniar dalam penelitiannya "Hubungan Antara Dukungan Sosial Orangtua dengan Kecemasan Menghadapi Dunia Kerja pada Siswa Kelas XII" dengan korelasi sebesar $-0,519$ dengan nilai signifikansi sebesar $p=0,000(p<0,05)$. Nilai tersebut menunjukkan bahwa terdapat hubungan negativ antara variabel dukungan sosial orangtua dengan kecemasan menghadapi dunia kerja pada siswa kelas XII SMK Yudya Karya Magelang. ${ }^{17}$

Pada penelitian ini subjek berusia 20 - 24 tahun. Hal ini berarti subjek dalam penelitian ini tergolong dalam kategori dewasa. Pengertian kedewasaan sendiri dapat diartikan sebagai individu yang sudah mencapai perkembangan yang penuh. Masa dewasa awal dengan rentan umur 20-24 tahun memiliki tugas perkembangan diantaranya yaitu mampu bertanggung jawab atas dirinya dan mulai menitik karir dalam rangka memantapkan kehidupan ekonomi rumah tangga. Setelah menyelesaikan pendidikan formal setingkat SMA, atau universitas, umumnya dewasa muda mulai memasuki dunia kerja, guna menerapkan ilmu dan keahliannya. Mereka senantiasa berupaya menekuni karier sesuai dengan minat dan bakat yang dimiliki. Serta memberi jaminan masa depan dn keuangan yang baik.

Berdasarkan hasil penelitian yang dilakukan pada mahasiswa Fakultas Dakwah Universitas Islam Negeri Sulthan Thaha Saifuddin Jambi, terdapat sebanyak 27 (26, 73\%) memiliki tingkat dukungan sosial yang tinggi, dan 66 $(65,34 \%)$ pada taraf sedang dan 8 ( $8 \%$ ) rendah. Hal ini menunjukkan bahwa subjek merasa mendapatkan dukungan sosial dari keluarga, teman sebaya maupun lingkungan sekitar. Adanya dukungan sosial yang diperoleh membuat subjek merasa bahwa mereka memiliki teman, keluarga yang memperhatikan, menghargai, dan saling berempati satu sama lain. Hal ini di dukung dengan pendapat Cohen Dan Wills dalam Daniel Rizky Wijaksono Menjelaskan bahwa seseorang dengan tingkat dukungan sosial yang tinggi

17 Devinda Priska Sekarina, Yeniar Indriana, Hubungan Antara Dukungan Sosial Orangtua Dengan Kecemasan Menghadapi Dunia Kerja Pada Siswa Kelas XII Smk Yudya Karya Magelang, Jurnal Empati, Vol. 7, No. 1, 2018, hlm. 383. 
memiliki rasa kepemilikan dan harga diri yang baik dari pada seseorang yang memiliki dukungan sosial yang rendah. ${ }^{18}$

Dukungan sosial bisa efektif dalam mengatasi tekanan psikologis pada masa sulit dan menekan. Misalnya, dukungan sosial dari orangtua membantu siswa untuk mengatasi stresor dalam masa-masa menghadapi dunia kerja. ${ }^{19}$ Menurut Taylor, dkk dukungan sosial menjadi salah satu faktor yang berupa bantuan secara materi, bantuan secara emosional, maupun bantuan informasi. Dukungan sosial dapat membantu subjek dalam menghadapi kecemasan dunia kerja. ${ }^{20}$

Hasil penelitian menunjukkan sebanyak 12 (12\%) memiliki tingkat kecemasan yang tinggi dalam menghadapi dunia kerja. Sisanya sebanyak 68 $(67,32 \%)$ berada ditingkat sedang dan 21 (21\%) memiliki tingkat kecemasan dalam menghadapi dunia kerja yang rendah. Hal ini juga selaras dengan penelitian yang dilakukan oleh Mahbub Nadziri dalam penelitinnya "Kecemasan mengadapi dunia kerja pada mahasiswa akhir dengan jurusan yang diprediksi sulit mendapatkan pekerjaan" dengan hasil penelitian menunjukkan bahwa subjek lebih banyak berada pada kategori kecemasan menghadapi dunia kerja yang sedang, yaitu sebanyak 47 mahasiswa (47.5\%). Sedangkan dengan kategori rendah 27 mahasiswa (27.3\%) mahasiswa, dengan kategori kecemasan menghadapi dunia kerja tinggi sebanyak 25 mahasiswa $(25.3 \%)^{21}$ Berdasarkan hasil persentase diatas, menurut Daradjat dalam Daniel Rizky Wijaksono hal yang ditakutkan atau dikhawatirkan dalam menghadapi karier masa depan adalah sempitnya lapangan kerja dan persaingan yang ketat dalam bidang pekerjaan. Hal ini di dukung oleh teori Nevid, Ratus dan Greene menyatakan bahwa salah satu sumber kecemasan seseorang adalah karir. ${ }^{22}$ Berdasarkan uraian tersebut dapat disimpulkan bahwa dukungan sosial berkorelasi dengan kecemasan mahasiswa menghadapi dunia kerja.

\section{Penutup}

Berdasarkan uraian di atas dapat disimpulkan bahwa data dukungan sosial yang diolah melalui program SPSS versi 16.0 menunjukkan tingkat dukungan sosial pada mahasiswa Fakultas Dakwah UIN Sulthan Thaha Saifuddin Jambi

18 Daniel Rizky Wijaksono, Hubungan Antara Dukungan Sosial Dengan Kecemasan Mahasiswa Dalam Menghadapi Dunia Kerja Pada Siswa SMK, Yogyakarta: USD, 2016, hlm. 45.

${ }^{19}$ Devinda, Yeniar, Hubungan Antara Dukungan Sosial Orangtua Dengan Kecemasan Menghadapi Dunia Kerja Pada Siswa Kelas XII SMK Yudya Karya Magelang, Jurnal Empati, Vol. 7, No. 1, 2018, hlm. 384.

20 Taylor, S.E, Peplau, L.A, dan Sears, D.O, Psikologi Sosial (Terjemahan), Jakarta: Kencana Prenada Media Group, 2009, hlm. 384.

21 Nadziri Mahmud, Kecemasan Menghadapi Dunia Kerja Pada Mahasiswa Akhir Dengan Jurusan Yang Diprediksi Sulit Mendapatkan Pekerjaan, Malang: UMM, 2018, Hlm. 11.

22 Daniel Rizky Wijaksono, Hubungan Antara Dukungan Sosial Dengan Kecemasan Mahasiswa Dalam Menghadapi Dunia Kerja Pada Siswa SMK, Yogyakarta: USD, 2016, hlm. 46. 
yaitu dari 101 mahasiswa sebanyak 27 (27\%) memiliki tingkat dukungan sosial yang tinggi dan sebanyak $66(65.34 \%)$ memiliki tingkat dukungan sosial yang sedang, kemudian sebanyak 8 (8\%) memiliki tingkat dukungan sosial yang rendah. Tingkat kecemasan pada mahasiswa Fakultas Dakwah UIN Sulthan Thaha Saifuddin Jambi yaitu sebanyak 12 (12\%) memiliki tingkat kecemasan menghadapi dunia kerja tinggi, dan sebanyak 68 $(67.32 \%)$ memiliki tingkat kecemasan menghadapi dunia kerja sedang. Sebanyak 21 (21\%) memiliki tingkat kecemasan menghadapi dunia kerja rendah. Kemudia berdasarkan penelitian yang dilakukan terdapat korelasi atau yang signifikansi antara dukungan sosial dengan kecemasan mahasiswa dalam menghadapi dunia kerja di Fakultas Dakwah UIN Sulthan Thaha Saifuddin Jambi. Hal ini dibuktikan berdasarkan hasil uji korelasi product moment, didapatkan koefisien korelasi sebesar 0,472 dengan nilai signifikansi sebesar 0, $000(\mathrm{p}<0,05)$. Sehingga H0 ditolak dan Ha diterima. Jika dilihat dari hasil nilai pearson correlation sebesar 0,472 itu berarti hubungan antara kedua variabel cukup kuat.

\section{Bibliografi}

Calvin S Hall \& Cardner Lindzey, Psikologi Kepribadian 1 Teori-Teori Psikodinamik (Klinis), Yogyakarta: Kanisius, 2005.

Daniel Rizky Wijaksono, Hubungan Antara Dukungan Sosial Dengan Kecemasan Mahasiswa Dalam Menghadapi Dunia Kerja Pada Siswa SMK, Yogyakarta: USD, 2016.

Devinda, Yeniar, Hubungan Antara Dukungan Sosial Orangtua Dengan Kecemasan Menghadapi Dunia Kerja Pada Siswa Kelas XII SMK Yudya Karya Magelang, Jurnal Empati, Vol. 7, No. 1, 2018.

Edy, SPSS + AMOS, Bogor: In Media, 2014.

Ernia Yunita, Hubungan antara Kepercayaan Diri dengan Kecemasan Menghadapi Dunia Kerja pada Mahasiswa Semester Akhir Universitas Muhammadiyah Surakarta, Surakarta : UMS, 2013.

Fani kumalasari, Hubungan Antara Dukungan Sosial Dengan Penyesuaian Diri Remaja Di Panti Asuhan, Jurnal Psikologi Pitutur, Vol. 1, No.1, 2012.

M. Nur Ghufron \& Rini Risnawati S, Teori-teori Psikologi, Jogyakarta: AR-RUZZ MEDIA, 2017.

Mahbub Nadziri, Kecemasan menghadapi Dunia kerja pada Mahasiswa Akhir dengan Jurusan yang Diprediksi Sulit Mendapatkan Pekerjaan, Malang: UMM, 2018.

Nursalam, Ninuk Dian Kurniawati, Asuhan Keperawatan Pada Pasien Terinfeksi, Jakarta: Salemba Medika, 2007.

Taylor, S.E., Peplau, L.A., dan Sears, D.O, Psikologi Sosial (Terjemahan), Jakarta: Kencana Prenada Media Group, 2009.

Widhi Nugrahaningtyas, Hubungan antara Efikasi Diri dan Dukungan Sosial Keluarga dengan Kecemasan Menghadapi Dunia Kerja pada Siwa Kelas XII SMK Muhammadiyah 1 Wedi Klaten, Jurnal Ilmiah Psikologi Candrajiwa, Vol. 3, No.2, 2014. 